Manuscript No. : : TPJSI-201912

Title

: China's Arctic policy: present and future

\title{
China's Arctic policy: present and future
}

\begin{abstract}
The article examines China's Arctic policy features and the meaning of the first published White Paper of 2018 for the future behaviors of the PRC. The author reviews the interests of the PRC in the High North, and the political objectives and means. The article pays special attention to the origins of Chinese policy in the Arctic, including the national strategy, expert discourse, and regional specifics. The author discusses the role of the Chinese public and private actors for the implementation of national achievements in the circumpolar region. The article examines Chinese interpretations of key international documents regulating activities in the Arctic, and the significance of these interpretations for the implementation of the PRC policy. The special emphasis is made of the diplomacy features and the role of the "soft" and "hard" power when China is interacting with different actors. The author explores the interconnection of the White Paper "China's Arctic Policy" with the implementation of the "Arctic Silk Road". As an outcome, the author indicates principles explaining China's Arctic behaviors in the longterm perspective.
\end{abstract}

Keywords: Arctic; China; China's policy; White Paper; Arctic Silk Road.

\section{Introduction}

Prior to the publication of the White Paper, China's Arctic behaviors gave rise to discussions about the longterm plans and principles of the PRC diplomacy in relations with other actors. A variety of scientific works outside of China were devoted to the country's policy in the Arctic - from the comprehensive analysis (Stensdal, I, Tonami, A. Jakobson, L., Lee, S.-H., Rainwater, S., Konyshev V., Sergunin A., Kobzeva M., Komissina I.) to studying individual aspects such as security, influence on the Scandinavian countries, strategic interests, etc. (Dwyer W. G. III, Kossa, M., Sørensen, C.T.N, Klimenko, E., Krovorotov A.K., Tulupov D.). ${ }^{1}$ At the same time, noting the ambivalence of PRC diplomacy which includes simultaneous

${ }^{1}$ Stensdal, “Asian Arctic Research 2005-2012: Harder, Better, Faster, Stronger”; Jakobson, and Lee, “The North East Asian states' interests in the Arctic and possible cooperation with the Kingdom of Denmark"; Dwyer III, "China's Strategic Interests in the Arctic"; Rainwater, "Race to the north: China's Arctic strategy and Its implications"; Kossa, 
peaceful declarations and assertiveness towards participation in regional development, experts have been considering it through the lens of China's foreign policy ambitions. Nevertheless, the influence of regional specifics, the development of 'discursive power' and other internal political factors remained beyond the focus or were interpreted more like symptoms. Concurrently, the growing number of Chinese authors was attempting to cover all possible topics and give a comprehensive assessment of the Arctic policy. At the same time, the outcomes of these articles often came down to looking for a model for China's participation in Arctic affairs. $^{2}$

The publication of the official document, it would seem, could have clarified the situation; however, experts have estimated the document differently. For instance, Sørensen, N. C. T., and Lajeunesse, Adam, believe that the White Paper is an indicator of China's strategic interest in the region and a step towards a more confident policy. ${ }^{3}$ Hong Nong and Xinmin M.A. suppose that the document is China's attempt to clarify its intentions and demonstrate the willingness to build strategic cooperation; thus, they pay special attention to how the document reflects the previously announced ideas. In general, many experts have come to the

"The rise of China in the Arctic? Domestic motives, actors and international context"; Tonami, "Asian Foreign Policy in a Changing Arctic. The Diplomacy of Economy and Science at New Frontiers"; Sørensen, and Klimenko. "Emerging Chinese-Russian cooperation in the Arctic: Possibilities and constraints"; Tulupov, "Skandinavskiy vektor arkticheskoy politiki Kitaya”; Krivorotov, “Arkticheskaya aktivizatsiya Kitaya: vzglyad iz Skandinavii”; Komissina, "Arkticheskiy vektor vneshney politiki Kitaya"; Konyshev, and Sergunin, "Osvoyeniye prirodnykh resursov Arktiki: puti sotrudnichestva Rossii s Kitayem v interesakh budushchego"; Konyshev, and Kobzeva, "Politika Kitaya v Arktike: traditsii i sovremennost"'.

${ }^{2} \mathrm{Li}$, "Zhongguo canyu beiji hangxian guoji jizhi de zhang'ai ji duice”; Liu, “'Yidai yilu' zhanlue beijing xia de beiji hangxian kaifa liyong"; Lu, "Nuowei dui si wa'er ba de qundao guanxia quan di xingzhi bianxi - yi yun si pi ci bei er gen qundao tiaoyue zui wei shijiao"; Pan, and Zheng. "Beiji diqu de zhanlue jiazhi yu zhongguo guojia liyi yanjiu"; Sun, and Guo, "Beiji zhili jizhi bianqian ji zhongguo de canyu zhanlue yanjiu"; Wang, "Jiyu SWOT fenxi fa yanjiu woguo beiji youqi hezuo zhanlue"; Yang, Liu, and Xin. "Woguo zengqiang zai beiji diqu shi zhi xing cunzai de shixian lujing yanjiu".

${ }^{3}$ Sørensen, "China as an Arctic Great Power. Potential Implications for Greenland and the Danish Realm"; Lajeunesse, "Finding 'Win-Win' - China's Arctic Policy and What it Means for Canada". 
conclusion that the document rather repeats previous statements. ${ }^{4}$ Chinese authors, in turn, actively joined in the discussion of the document and began to propose new approaches to the management of the Arctic based on the White Paper's thesis. ${ }^{5}$ However, is the document really nothing new? - This question remains controversial. In this regard, the study aims to examine the indicated problem, taking into account the previous studies of the author towards China's Arctic policies' formation, and to clarify, what role does China seek to play in the Arctic affairs? To what extent are the principles mentioned in the White Paper consistent with China's real policy, and which of the theses show the long-term trend of China's policy?

The research materials relate to the activities of the PRC in the Arctic from the moment of its activation in the late 1990s, when regular Arctic research began, until the publication of the White Paper and include international documents, Chinese documents and official statements towards the Arctic, as well as expert publications in Chinese, English, and Russian.

In the course of the study, the author maintains the neorealist views on international politics, and specifically, the thesis of J. Mearsheimer on the natural desire of China, as a major power, to expand its sphere of influence. ${ }^{6}$ Such an approach allows critically exploring the activities of the PRC in the Arctic and assessing the conflict potential of the international environment where the national interests of the participants limit cooperation.

The author used an institutional method for studying the elements of China's decision-making system for the Arctic, including key institutions of the PRC's, and the range of Arctic actors, including countries and international organizations, interacting with China.

${ }^{4}$ Hong, "China's Interests in the Arctic: Opportunities and Challenges", 1; Xinmin, "China's Arctic policy on the basis of international law: Identification, goals, principles and positions"; Lim, "China's Arctic Policy \& the Polar Silk Road Vision".

${ }^{5}$ Feng, "Zhongguo de beiji zhengce yu beiji shengtai huanjing gongtongti de goujian——yi beiji huanjing guoji fazhi wei shijiao"; Wang, and Cui. "Yidai yilu" kuangjia xia de beiji guoji hezuo: Luoji yu moshi"; Li, "Ruhe zhunque lijie zhongguo de beiji zhengce"; Feng, "Zhongguo beiji zhengdang quanyi ying shou zunzhong".

${ }^{6}$ Mearsheimer, Can China Rise Peacefully? 
The first part of the article provides a general description of China's policy in the Arctic, such as its origins, key actors, the specifics of interpreting the legislative documents, which are fundamental to China, and the peculiarities of China's diplomacy regarding various Arctic actors. The second part of the article is devoted to a new document, an analysis of its content, the reasons for publication and link with the 'Arctic Silk Road' initiative. In conclusion, the author offers her own reading of the White Paper and determines the basic principles of future China's Arctic policies.

\section{Basis of China's Arctic policy}

\section{Origins of the Arctic policy}

The specifics of the formation of China's Arctic policy is that it is not only the CPC policy, as it may seem if we would consider solely the documents and speeches of officials. Our previous research has shown that three internal factors shape China's Arctic policy. ${ }^{7}$

Firstly, it is the national strategy, inspired by the ideas of the 'Chinese dream' and the 'Belt and Road'. According to the 18th Party Congress' decisions, China should take advantage of the 'period of strategic opportunities', achieve economic prosperity and globally play the role of 'major responsible country' ${ }^{8}$ This message applies to all significant policy directions, including the Arctic, and is reflected in the theses of the White Paper.

In this regard, it is indicative of how the Arctic activities have gradually joined the state agenda of the PRC. The first document, which mentioned the Polar Regions was the National Security Law of the People's Republic of China (2015), which considered China's possible participation in rescue and military operations outside the country. Secondly, the $78^{\text {th }}$ point of the list of 100 events planned for a period of the $13^{\text {th }}$ five-year

\footnotetext{
${ }^{7}$ Kobzeva, “Arkticheskiy vektor v politike Kitaya pri novom rukovodstve”, 962-965.

${ }^{8}$ Embassy of the PRC. Full text of Hu Jintao's report at 18th Party Congress.
} 
plan mentioned the construction of a new icebreaker and cooperation on the basis of new observation stations in the Arctic. ${ }^{9}$

In 2017, the Arctic appeared in the "Vision for Maritime Cooperation under the Belt and Road Initiative». China called on states to cooperate in the construction of the BRI in the Arctic, extracting resources, shipping, participating in the activities of international organizations, and so on. ${ }^{10}$

Finally, the White Paper confirmed the close relationship between the Arctic policy and national strategy of the PRC. The document positioned China, as a 'responsible power', which intends to take an active part in the study and development of the Arctic, as well as in the governance in the region. In addition, China proposed the 'Arctic Silk Road' (hereinafter referred to as ASR), thus including the region into the BRI, the key project of modern China and the way to the 'Chinese dream' to come true. ${ }^{11}$

Secondly, Chinese experts actively involved in the conceptual development of the Arctic policy. The government set to scholars the task to form the so-called 'discursive power' of the country (话语权), in other words, to promote concepts at the international level. ${ }^{12}$ Over the years preceding the White Paper, Chinese scientists' elaborations remained an important source of information on how China perceives the country's role in the Arctic. Moreover, as our previous studies have shown, variations on how the Arctic may look like due to the China's participation and what role the PRC can (or even have to) play in the region, represent a rather patchy picture. From the most moderate assessments, which to the point repeat the statements of officials, ${ }^{13}$ up to the bright theses of Li Zhengfu about the Big Arctic, which may include not only non-Arctic

\footnotetext{
${ }^{9}$ Xinhua News Agency. Shouquan fabu: Zhonghua renmin gongheguo guojia anquan fa; National People's Congress (NPC) of the People's Republic of China. "Shisanwu” tixian zhongguo guojia zhanlue de bai da gongcheng xiangmu ${ }^{10}$ Xinhua News Agency. Full text: Vision for Maritime Cooperation under the Belt and Road Initiative.

${ }^{11} \mathrm{Wu}$, "Xijinping quanqiu jingji zhili de xin sixiang yu xin shijian", 11, 15; Konyshev, and Kobzeva, "Politika Kitaya v Arktike: traditsii i sovremennost", 81,88 .

${ }^{12}$ The State Council Information Office of the People's Republic of China. Zhang, Zhizhou. "Guoji huayu quan jianshe zhong ji da jichu xing lilun wenti”.

While the English version of the 'China's Arctic Policy' White Paper offers the term 'Polar Silk road', the more accurate term would be 'Arctic Silk Road'.

${ }^{13}$ Kobzeva, "Protivorechiya v otsenkakh arkticheskoy politiki KNR", 214-217.
} 
actors that have already declared themselves, but also such countries as Mongolia, Kazakhstan, Kyrgyzstan, Uzbekistan, Turkmenistan, Tajikistan and Afghanistan. Either the idea of experts from the Central China Normal University towards the perspective of China's 'creative intervention' [创造性介入] into the Arctic policy, namely intensifying China's efforts in the low politics sphere, promoting the interests of non-Arctic countries. ${ }^{14}$

It is also worth noting the military dimension of Chinese discourse. Assessing the military-strategic potential of the Arctic for the PRC, a number of experts consider it possible to play the card in the region. In connection with a decrease in the US participation in the policies of the Nordic countries and a growth of Russia's military potential, experts discuss an option for China to act as a kind of a new guarantor of security. Or, if the United States will try to force the PRC out of the region, to develop a partnership with Russia in order to ensure sustainable Arctic activities. ${ }^{15}$

Although many statements by Chinese experts should not be automatically attributed to the position of China's leadership, as it has happened in the case with the quote of Rear Admiral Yin Zhuo, it is necessary to take into account the fact that officials actively use a significant part of formerly debatable theses. ${ }^{16}$ For example, the thesis 'China is a near-Arctic state' has circulated among scholars in the past five years and now it is tightly bound with Chinese Arctic behaviors. In addition, the concept 'the Arctic is the common heritage of mankind', which for a long time was discussed among Chinese experts, is now fixed in the softer formula a 'shared future for mankind in the Arctic region'. ${ }^{17}$ It seems that the scientific community acts as in the wellknown Chinese proverb 'to cross the river by feeling the stones'. Like the pioneers, experts generate concepts, study the international community response and offer the most effective theses. Thus, experts' discourse gradually animates the political rhetoric.

${ }^{14} \mathrm{Li}$, Da beiji shijiao xia de fan dongbei ya”, 27; He, and Song, “Chuangzaoxing jieru: Zhongguo canyu beiji diqu shiwu de tiaojian yu lujing tansuo", 53, 55-56.

${ }^{15}$ China-Nordic Arctic Research Center Newsletter. 3nd Issue; Huang. “Zhongguo beiji quanyi de weihu lujing yu celue xuanze", 82.

${ }^{16}$ Kobzeva, "Protivorechiya v otsenkakh arkticheskoy politiki KNR", 214-217.

17 The State Council of the People's Republic of China. Full Text: China's Arctic Policy. 
The third component is the regional specifics. The outcomes of our previous study on the range of regions' involvement in the implementation of China's Arctic policy shows that each entity (province or large city) sees its own role in the implementation of national interests. Such variability is associated with historical heritage, various opportunities, and priorities. The clear example is the Heilongjiang Province' relations in the Arctic. Since the local government expects to participate in the Arctic development, to this end, the province is developing cooperation with the Russian Murmansk and Arkhangelsk. In turn, Shanghai is actively developing shipping and is exploring prospects for cooperation with various northern countries' seaports. ${ }^{18}$

Among other things, we have found that positions and topics for discussion in the scientific community also have regional dependence. For example, it was found that metropolitan scholars primarily consider the energy cooperation of the PRC, while the Shanghai experts insist on the urgent need to improve the Arctic legislation, develop shipping and scientific research, and experts from coastal provinces actively examine the prospects of expanding the rights of non-Arctic countries. ${ }^{19}$

As a result, all three components, the national strategy, expert discourse, and the regional component, are involved in decision making and gradually shape China's Arctic policy.

\section{From interest to stratagem}

The interests of China, like of any Arctic actor, include many components - from participation in the development of resources to the improvement of legal mechanisms. Within the framework of the article, it seems appropriate to emphasize how each component correlates with the national interests of the PRC and how China strives for it.

Primarily, it is worth noting the interests, associated with a favorable position and natural resources of the region. Firstly, the Arctic is within the radar of the military-strategic interests of the PRC - both due to the fact that the polar region partially includes the Bering Strait, where the interests of China, the United States, Japan and Russia overlap, and due to the fact that China intends to develop Arctic shipping and is naturally

\footnotetext{
${ }^{18} \mathrm{Xu}$, "Interesy i politika Kitaya v Arktike: istoriya, pravovyye osnovy i realizatsiya", 58.

${ }^{19}$ Kobzeva, "Protivorechiya v otsenkakh arkticheskoy politiki KNR”, 214-217.
} 
interested in ensuring maritime security. For that reason, China seeks to develop its own technologies and train personnel capable to work in the High North. ${ }^{20}$

As known, China's activities in the Arctic in this direction are developing not without excesses, if we recall the episode with Chinese ships navigating close to the coast of Alaska. ${ }^{21}$ Nevertheless, China's participation in the conflict in the Circumpolar North seems unlikely, both because of the lack of adequate technologies, and because the international strife will threaten Chinese Arctic projects along the BRI. In this connection, PRC experts unanimously condemn the trend towards militarization of the Arctic. ${ }^{22}$

Just as much China is interested in the development of Arctic logistics. In recent years, the topic of the development of China's Arctic shipping, as well as the possibility of including the northern routes in the 'Belt and Road' initiative has become one of the most discussing topics among Chinese experts. ${ }^{23}$ According to preliminary estimates, shipping in the region promises to increase China's trade with European countries from 10.95 to $20 \%$ and to contribute to ensuring energy security due to diversifying fuel supply routes. ${ }^{24}$ Such an alluring prospect is pushing China to participate seriously in the development of Arctic logistics, railways, and ports construction, and to build its own icebreaking fleet. ${ }^{25}$ Besides, China is actively investing in the infrastructure of the Arctic actors. For instance, the PRC invests in the construction of the port in Sabetta

${ }^{20} \mathrm{Li}$, Zhan and Ma, "Zhongguo kaifa haishang dongbei hangdao de zhanlue tuijin gouxiang”, 50; Feng, "Beiji hangdao tonghang dui dongbei ya de zhanlue yiyi”, 91-92; Li, Zhan and Ma, “Zhongguo kaifa haishang dongbei hangdao de zhanlue tuijin gouxiang", 50 .

${ }^{21}$ Washington Post. Chinese naval ships came within 12 nautical miles of American soi.

${ }^{22} \mathrm{Ni}$, and Li. "Zhongguo beiji zhengce de xianzhuang yu qianjing"; Zhang, and Huang. "Zhongguo beiji quanyi de weihu lujing yu celue xuanze", 75-76; Li, Zhan, and Ma, "Zhongguo kaifa haishang dongbei hangdao de zhanlue tuijin gouxiang", 50 .

${ }^{23}$ Ibid., 27, 28; Li, and Hu, "Beiji hangdao" kaitong yu zhongguo ji qi shou yingxiang quyu de maoyi zengzhang qianli fenxi”, 429, 437.

${ }^{24}$ Yang, "Diyuan keji xue yu guojia anquan: Zhongguo beiji ke kao de zhanlue shenyi", 131; Li, Zhan, and Ma, "Zhongguo kaifa haishang dongbei hangdao de zhanlue tuijin gouxiang", 48-49.

${ }^{25}$ Pan and Lu. “"Beiji diqu de zhanlue jiazhi yu zhongguo guojia liyi yanjiu”, 119, 123; Konyshev and Sergunin, "Strategii stran Vostochnoy Azii v Arktike", 38; Xinhua News Agency. China's ice breaker sets sail for Arctic rim expedition; Cai, COSCO. Arctic Circle 2015. 
(linked to the 'Yamal LNG'), in Murmansk port, and Arkhangelsk port (associated with the construction of the 'Belkomur' railway with Chinese participation), leases the ports of North Korea, etc. ${ }^{26}$ Thus, today, when the ASR came out of backstage discussions to the official level, the basis for its implementation is about ready.

The integral part of the ASR is mining. By optimistic estimates, the Arctic will provide up to $60 \%$ of the country's ever-growing need for fuel. ${ }^{27}$ It is fitting that China's participation in this field is particularly noticeable. Today, in all Arctic countries, there are companies with varying degrees of Chinese involvement. The PRC buys shares in extracting companies, purchase exploration rights, concludes long-term supply contracts, and develops design-and-engineering for the Arctic. ${ }^{28}$ Thus, as W. Ostreng wrote in 2013, the 'Arctic Silk Road' will likely unite Arctic mining projects with Chinese participation. ${ }^{29}$

The last one area related to the region's natural resources is aquatic bioresources, in which China, as one of the largest consumers, is also in constant need. China actively cooperates with the northern countries on the issue of legal regulation and organization of the future fishing in the Central Arctic Ocean. ${ }^{30}$ Having entered into negotiations, China has identified its substantial interest and now has a good reason to prepare for the Arctic fishing. ${ }^{31}$

It is worth noting, however, that China's success in the areas listed above has an additional economic effect. On the one hand, the implementation of many projects, as well as the pursuit to lead an activity mostly independent from other countries, contribute to the development of new technologies - from solving

${ }^{26}$ Sina Corp. Zhongguo huo chao gangkou 30 nian shiyong quan han mei cheng xi liyong chaoxian; Staalesen, Murmansk counts on Chinese investors.

${ }^{27}$ Deng, "Shipping Matters: The Role of Arctic Shipping in Shaping China's Engagement in Arctic Resource Development," 63-67; Zha, Arctic Geopolitics: a view from China Arctic Frontiers 2015; Baranikova, and Chen. “Zhongguo beiji zhengce de xianzhuang yu qianjing”, 25-27.

${ }^{28}$ To name some of them: Nexen in Canada, Yamal LNG in Russia, Elkem in Norway, Kvanefjeld project in Denmark, AAVI Technologies Ltd. in Finland, Elkem Iceland, etc.

Zha, Arctic Geopolitics: a view from China Arctic Frontiers 2015.

${ }^{29}$ Østreng, et all, Shipping in Arctic Waters. A comparison of the Northeast, Northwest and Trans Polar Passages, $72-$ 75.

${ }^{30}$ Pan, "Self-Organization: The Governance of CAO Fisheries in the Global Commons", 20-22.

${ }^{31}$ Liu, Why is China so quiet in negotiations about fisheries in the central Arctic Ocean? 
engineering problems of shipbuilding and resource extraction to the development of green, environmentally friendly technologies. The latter is a particular area for cooperation between the PRC and the Scandinavian countries, Canada and the USA. ${ }^{32}$ On the other hand, China's Arctic activities open up the possibility for the development of the Northeast of the country, in particular, the cities of Dalian, Tianjin, Qingdao, Hunchun, etc., which are potentially able to integrate into the ASR infrastructure. ${ }^{33}$ In addition, cooperation in the Arctic may help the solution of a number of issues in the Asia-Pacific region via the beneficial cooperation with Japan and South Korea. The reason for such an effect is these countries' shared interest towards the peace in the North Pacific and the development of the Arctic shipping. Finally, the growing influx of Chinese visitors to the region significantly contributes to the development of the travel industry of the PRC. ${ }^{34}$

The realization of the mentioned interests hinges on the country's status as a legitimate actor and its body of knowledge on the Arctic. In this regard, the development of Polar Science and the participation in the Arctic governance remain the vital tasks. For that reason, both topics constantly appear in Chinese officials' statements and documents, including the White Paper. The latter highlights these directions as priority ones. ${ }^{35}$

It is worth noting that the protection of legal rights of non-Arctic countries, including the advocacy towards the freedom of navigation, also repeatedly identified in the document as an important task, closely relates to the development of the discursive power of the PRC. Success in this field coupled with effective

${ }^{32}$ Hallding, China's Arctic Ambitions - actors, drivers and strategies?; Feng, "Beiji hangdao tonghang dui dongbei ya de zhanlue yiyi”, 91, 92; Pan, and Lu, "Beiji diqu de zhanlue jiazhi yu zhongguo guojia liyi yanjiu", 119, 123.

${ }^{33}$ Zhang, and Huang, "Zhongguo beiji quanyi de weihu lujing yu celue xuanze”, 75-76; People's Daily. Zhong e gong jian zha lu bi nuo gang; Dou, "Dongbei ya sichou zhi lu yu zhongguo "yidai yilu” zhanlue de tazhan”, 70-71.

${ }^{34}$ Yang, "Diyuan keji xue yu guojia anquan: Zhongguo beiji ke kao de zhanlue shenyi", 120; Hallding, China's Arctic Ambitions - actors, drivers and strategies?; Feng, "Beiji hangdao tonghang dui dongbei ya de zhanlue yiyi”, 91, 92; People's Daily. Shou lun zhong ri han sanguo beiji shiwu gao jibie duihua zai shou'er juxing.

${ }^{35}$ Ministry of Foreign Affairs of the PRC. Zhang Ming. Vice-Foreign Minister, PRC. Keynote Speech by Vice Foreign Minister Zhang Ming at the China Country Session of the Third Arctic Circle Assembly; The State Council of the People's Republic of China. Full Text: China's Arctic Policy. 
and maximally independent activity are able to prepare the country to a 'favorable moment' when, according to Chinese scholars, circumstances will allow to fully engaging in the Arctic development. ${ }^{36}$

In this perspective, China from the modest participant of the Arctic affairs may turn to be an actor who will gradually refine the rules in its favor. In this case, the policy of the PRC in the circumpolar region will become a modern illustration of the ancient Chinese stratagem 'to make the host and the guest exchange roles', of course, with the amendment that this will only apply to certain aspects of legal regulation, and not to sovereignty.

\section{Policy actors}

China's Arctic breakthrough is the result of joint efforts of state agencies, Chinese business, and 'soft power' actors. On the top is a divergent structure of organizations, the most significant of which are the Interagency Coordinating Mechanism on Arctic Affairs (the division at the Department of Treaty and Law of the Ministry of Foreign Affairs) and the State Oceanic Administration (SOA). The first one is responsible for China's international relations and seems nonpublic. The second one controls, organizes and finances economic and scientific activities. ${ }^{37}$ Both organizations through a series of higher authorities, report to Xi Jinping.

The prominent role the Chinese Advisory Committee for Polar Research plays, which brings together representatives from fourteen ministries and departments, including the Ministry of Land and Natural Resources, manages SOA. Each ministry participates in the implementation of national interests in the Arctic and reports to either the State Council, which makes decisions on the financial support, or the People's Liberation Army General Staff Department. The committee work is nonpublic, however, this organization is obviously an important element in the decision-making process towards Arctic activities. ${ }^{38}$

\footnotetext{
${ }^{36}$ Wang and Wang, "Zhongguo ruhe yingdui beiji diqu xingshi xin bianhua”, 34-36; Li, "Zhongguo canyu beiji hangxian guoji jizhi de zhang'ai ji duice", 101.

${ }^{37}$ China-Nordic Arctic Research Center Newsletter.

${ }^{38}$ Tonami, Asian Foreign Policy in a Changing Arctic. The Diplomacy of Economy and Science at New Frontiers, 30; Ministry of Land Reform. Zhongguo jidi kaocha gongzuo zixun weiyuanhui di 17 ci huiyi zai shanghai zhaokai.
} 
The second place among actors of China's Arctic activities are corporations, which are entrusted with the duty of implementing the national plan. The annual reports of PRC companies note the achievements of Chinese science and innovative engineering solutions for the Arctic, thus cultivating national pride. The list of companies, and best performers of the Arctic development, includes the largest Chinese companies, such as CNPC, CNOOC, Sinopec, China National Bluestar, China Investment Corporation, Sinosteel, etc. For instance, the key impact on national Arctic navigation development is the progress of the COSCO. The leader of Chinese polar shipping, which annually tests Arctic sea routes, develops shipping, and conducts scientific research in the field of mineral exploration. ${ }^{39}$

Another source of particular pride is the construction of the first made-in-China research icebreaker, "Snow Dragon-2" (the ice class PC3), at the leading Chinese shipyard Jiangnan Shipbuilding (Group) Co., Ltd. Besides, China opened the bid to construct the first nuclear-powered icebreaker, which should become a powerful multipurpose vessel for the Arctic. ${ }^{40}$

The third group unites 'soft power' actors, who shape the image of China in the Arctic, both for the international community and for Chinese citizens. These are scientific institutions, tourist agencies, museums, media, cultural initiatives, and individuals: travelers, bloggers, and photographers. Thanks to their efforts, and to political support, people take more interest in the region and better understand the reasons for the national policy in such a remote land. As a result, the popularity of polar research in the PRC and the number of Chinese tourists in the circumpolar countries raises from year by year. ${ }^{41}$

${ }^{39}$ Such as CNPC Offshore Engineering Company, Qingdao McDermott Wuchuan, Honghua Group, Penglai Jutai Offshore Engeneering Heavy Industries Co Ltd., Evergreen Holding Group, Bomesc Offshore Engeneering Co Ltd., etc.

${ }^{40}$ CNPC. Ya ma'er, chuli beiji quan de LNG chaoji gongcheng; Jiangnan Shipyard (Group) Co., Ltd. Woguo shou zhi jidi ke kao pobingchuan jiang yu niandi kaigong, jiangnan zaochuan yu jidi zhongxin qianding jianzao hetong; Nilsen, "Details of China's nuclear-powered icebreaker revealed."

${ }^{41}$ Komissina, “Arkticheskiy vektor vneshney politiki Kitaya”, 55-57. 


\section{Law regulations}

Both before and after the White Paper publication, the crucial documents for China's Arctic policy remain with the UN Charter, the 1982 UN Convention on the Law of the Sea, the Svalbard Treaty and the Polar Code. ${ }^{42}$ Recognition of them is important for two reasons. First, it is helpful to stay a good partner of the northern countries, a full participant of the Arctic Council and a legitimate actor of the Arctic governance. Secondly, a number of articles in these documents allow fortunate interpretation, which shows the essence of the claims of the PRC.

Firstly, some Chinese experts appeal to article 52 of the UN Charter, which says that regional arrangements or agencies and their activities should be consistent with the Purposes and Principles of the United Nations. Otherwise, such agencies are in conflict with the Charter. That gives hope for a legitimate change in Arctic Council rules of procedure, since these scholars accuse the AC of monopolizing the Arctic. ${ }^{43}$

The other interpretation relates to the rules of navigation established by coastal states. The majority of Chinese experts appeal to article 234 of the UNCLOS, which requires "consideration of the best available scientific evidence". Through such a lens, the impossibility of free passage seems discriminatory. The article 77 which says that "coastal State exercises over the continental shelf sovereign rights", not the sovereignty, may also simplify the regime of navigation. The last mentioned is especially important for China in the case of extending the borders of the northern states' continental shelf. ${ }^{44}$ Such interpretation, in Chinese experts' opinion, should also prevail over the Svalbard Treaty. Based on the text of the Treaty, experts assert China's equal rights as a signatory, and oppose Norway's attempts to clip participants' powers. ${ }^{45}$

Alternatively, Chinese experts enthusiastically consider documents, such as the Polar Code, which involve China in their refinement. The negotiations on the management of fishing in the Central Arctic ocean

\footnotetext{
${ }^{42}$ The State Council of the People's Republic of China. Full Text: China's Arctic Policy.

${ }^{43}$ Yang, Liu and Xin, "Woguo zengqiang zai beiji diqu shi zhi xing cunzai de shixian lujing yanjiu", 79.

${ }^{44}$ Liao, "Beiji dalujia falu zhidu yanjiu", 64-65.

${ }^{45} \mathrm{Lu}$, "Nuowei dui si wa'er ba de qundao guanxia quan di xingzhi bianxi — yi yun si pi ci bei er gen qundao tiaoyue zui wei shijiao", 11; Konyshev and Kobzeva, "Shpitsbergen v arkticheskoy politike Kitaya”, 52, 53.
} 
are also promising. Chinese experts hope that active participation in the legislation improvement helps China to properly represent and assert the interests of non-Arctic countries. ${ }^{46}$

It is worth noting that all the above contradictions outline the sphere in which the PRC is ready to stand its ground actively - especially in case of any precedent. In support of such an attitude, the White Paper outlined the idea of respect to the rights of non-Arctic states as one of the cornerstones of China's policies. ${ }^{47}$

\section{Variable diplomacy}

All of the above shapes China's Arctic diplomacy, namely, its selective approach to cooperation with different actors. According to our previous studies' outcomes, we have chosen five criteria to describe the diplomacy of the PRC: the key thesis, identified in course of the analysis of the Chinese official and expert discourse, the image, which China seeks to maintain when interacting with various Arctic actors, the areas of cooperation, the use of 'hard' and 'soft' power. ${ }^{48}$

Among the Arctic actors, there are different points of view on the principles of Arctic governance, and their vision does not always coincide with the position of the PRC. This situation affects the Chinese diplomacy. For example, the Arctic Five is interested in observing the existing legal framework. Thus, when interacting with coastal circumpolar states, China presents itself as a near-Arctic state, insists on the equal partnership, and avoids discussing the future of the Arctic as a 'common heritage of humanity', especially, in relations with Russia and Canada. ${ }^{49}$

However, the topic of the 'common heritage' becomes relevant when collaborating with Scandinavian countries (except for Norway), EU-non-Arctic countries и South Asia countries, such as Malaysia, Thailand,

${ }^{46}$ Liu, "How Has China Shaped Arctic Fisheries Governance?"; Wu, Wu and Wang, "IMO Jidi guize he weilai jidi chuanbo fazhan qushi fenxi”, 9.

${ }^{47}$ The State Council of the People's Republic of China. Full Text: China's Arctic Policy.

${ }^{48}$ Kobzeva, Mariia. “Arkticheskiy vektor v politike Kitaya pri novom rukovodstve”, 969-971.

${ }^{49}$ Sun and Guo. "Beiji zhili jizhi bianqian ji zhongguo de canyu zhanlue yanjiu", 128; Ministry of Foreign Affairs of the People's Republic of China. Wang Yi buzhang zai di san jie beiji quan luntan dahui kaimu shi shang de shipin zhici. 
Singapore, etc. These countries are exploring the possibilities of liberalizing the shipping regime and increasing participation in the economic development of the northern territories. In this regard, their position is closer to China's in relation to the need of the Arctic governance improvement. Thus, when interacting with these states, China discusses the thesis of 'shared future for mankind in the Arctic', and with respect to Asian actors, is ready to position itself as a 'responsible power'. A striking example is the AFoPS initiative. As one of the leaders of it, China seeks to foster scientific cooperation between Asian countries, and to motivate them to develop their own strategies for Arctic research. ${ }^{50}$

In relations with Japan and South Korea, which also intend to participate actively in the development of the Arctic, there is a peculiarity as well. Taking into account the mutual discords, in Circumpolar North, a kind of competitiveness between them occurs. In order to overcome the emerging contradictions, a high-level trilateral dialogue has been organized since $2016 .{ }^{51}$ However, so far this initiative it did not yield any tangible results.

Similarly, the main areas of cooperation of the PRC vary. In the case of the northern countries, China primarily develops a comprehensive economic partnership and scientific cooperation. In the case of nonArctic EU countries, the promising areas are the Arctic governance, sustainable development of the circumpolar territories, scientific research and the rights of indigenous peoples. With the Asian countries, the spectrum of interaction is narrower and comes to scientific collaboration and discussions on the Arctic governance. This point related to both with the economic competition and in general, with the poorly developed Arctic policy of these states. ${ }^{52}$

Overall, since the Arctic is of strategic importance for China, the policy of the PRC relies on the recognition of the principles proposed by the Arctic Council, and involves the diverse use of 'soft power'. The

\footnotetext{
${ }^{50}{ }_{2}$ Members of the Asian Forum for Polar Sciences are China, Japan, S. Korea, Malaysia, and Thailand. Observers-states are Indonesia, Philippines, Sri Lanka, and Vietnam.

${ }^{51}$ Ministry of Foreign Affairs of the People's Republic of China. Di er lun zhong ri han beiji shiwu gao jibie duihua lianhe shengming.

52 Sino-Nordic Relations: Opportunities and the Way Ahead, 11; Sun, "Future Trends of Arctic Sustainable Development and Opportunities for U.S.-China Cooperation”, 23, 24.
} 
last mentioned includes scientific cooperation, tourism, the development of regional and humanitarian ties, the consolidation of discursive power and the formation of a positive image of China as a 'welcome guest'. This approach allows China to maintain an atmosphere of mutual confidence and cooperation. As for the use of 'hard power' by the PRC, today it is extremely limited and may be traced to China's attempts of economic influence when interacting with Nordic countries. ${ }^{53}$

Par to the course China's diplomacy towards various organizations also varies. It is worth noting that China is a member of most international organizations related to the Arctic. The major one, Arctic Council, does not give the PRC special advantages in promoting the interests of non-Arctic states. In this regard, the promising alternative is the country's participation in UN organizations with equality of participants, and in particular in the International Seabed Authority. Another platform is the Arctic Circle forum, which in a certain sense opens the door for China's 'discursive power' that is limited in the framework of the Arctic Council. $^{54}$

Due to the different powers of the PRC in the abovementioned organizations, the discussions on the 'shared future for mankind in the Arctic' are relevant in the UN structures (International Seabed Authority, Commission on the Limits of the Continental Shelf, IMO) and other international organizations and forums related to the Arctic. ${ }^{55}$ While that is not China's thesis for the Arctic Council.

In most of the organizations, China seeks to promote the image of an important Arctic stakeholder, which is legitimate since makes a significant contribution to the development of the region. However, in Asian

\footnotetext{
${ }^{53}$ Komissina, “Arkticheskiy vektor vneshney politiki Kitaya”, 69.

${ }^{54} \mathrm{He}$ and Sung, "Chuangzaoxing jieru: Zhongguo canyu beiji diqu shiwu de tiaojian yu lujing tansuo", 52, 55, 57; Ministry of Foreign Affairs of the People's Republic of China. Wang Yi: Zhongguo bingcheng zunzhong, hezuo yu gong ying san da zhengce linian canyu beiji shiwu..

${ }^{55}$ University of the Arctic; Ny-Ålesund Science Managers Committee; Arctic Circle; International Arctic Science Committee; China-Nordic Arctic Research Center; Forum of Arctic research operators; Pacific Arctic Group; NorthEast Asian Regional - Global Ocean Observing System; North Pacific Ocean Scientific Organization; Sustaining Arctic Observing Networks.
} 
organizations on the Arctic, as well as organizations where China's political capital is objectively low ${ }^{56}$, China uses the image of a 'responsible power', since it correlates with the PRC policy regarding global sustainable development. ${ }^{57}$

\section{The White Paper and steps forward}

\section{'China's Arctic policy'- what is it about?}

Almost twenty years after the first Arctic expedition of the "Snow Dragon" and the subsequent intensive political, economic, and research efforts in the Circumpolar North, China published the White Paper on the Arctic. This first document finally outlined China's view of the Arctic issues, as well as a policy regarding international cooperation and resources development: shipping routes, energy resources, water bioresources and opportunities for tourism. However, in our opinion, the document has not become a reiteration of previous statements. By contrast, it has avowedly shown the nature of China's policy in the Arctic.

It is worth paying attention to the causal relationships between the document's statements. China claims that Arctic issues are of a global impact and announce itself a 'responsible power'. Thereby, the PRC emphasizes its moral right and the obligation to take part in the development of the region and to contribute to the construction of a 'shared future for mankind in the Arctic'. ${ }^{58}$

Hence, it also follows that China has legitimate rights in the region. The document elaborates clearly that China understands the limitations of its rights, as well as adheres to existing rules. However, the PRC will persistently assert the rights it enjoys in accordance with international law (namely, for instance, the development of the international seabed area and the advantages of the Svalbard Treaty). It is crucially noting that the document does not infringe on the Arctic countries' rights, but it simply shifts the emphasis to the

\footnotetext{
${ }^{56}$ Asian Forum for Polar Sciences; Association of North East Asia Regional Goverments; Northeast Asian Gas and Pipeline Forum; Association of World Reindeer Herders.

${ }^{57}$ China welcomes Arctic Council's granting of observer status; 2016 Pacific Arctic Group (PAG), Fall Meeting Minutes.

${ }^{58}$ The State Council of the People's Republic of China. Full Text: China's Arctic Policy.
} 
equality of all participants, including non-Arctic actors and indigenous peoples. At that, the equality of these actors is a matter of principle to China as a 'responsible power'. ${ }^{59}$

Naturally, the two directions of China's policy appears. The first one is participation in the Arctic governance, which China understands as the right to "participate in regulating and managing the affairs and activities relating to the Arctic on the basis of rules and mechanisms" and jointly build a shared future for humankind. In this regard, the White Paper notes the importance of the Arctic Council for solving problems of ecology and sustainable development. However, the insufficiency of it for the region stays between the lines. In order to address the problems outside the $\mathrm{AC}$ competence China intent to take part in other international organizations: foremost, Arctic Science Ministerial Meeting, the Arctic Circle, Arctic Frontiers, 'The Arctic: Territory of Dialogue', CNARC. ${ }^{60}$

On the other hand, to fill the gap in economic development, China proposes the 'Arctic Silk Road', which requires the coordination of development strategies of all Arctic actors with a particular emphasis on shipping. To foster the initiative, China intends to promote its companies and research centers to participate in the ASR for the economic benefits of participants and regional development. ${ }^{61}$

The conclusion of the document unites the key elements of the policy. These ideas are: the 'shared future for mankind in the Arctic', 'China is a responsible major country', inclusive Arctic governance, and the ASR influence for good of the Arctic nations. Thus, the White Paper arranges a logical chain of arguments from these once debatable ideas and establishes the solid Arctic policy of the PRC.

\footnotetext{
59 Ibid.

60 Ibid.

61 Ibid.
} 


\section{Why did they publish?}

China's Arctic behaviors have been developing quite smoothly so far, and for a long time, the leadership of the PRC, in unison with Chinese experts, was delaying to release the policy. ${ }^{62}$ Thus, what was the reason to publish the White Paper?

The first, internal cause is that, against the background of the regional variability of the Arctic policy, the leadership was in need to setting a single vector. Strengthening the Xi Jinping's power after the 19th Congress was a strong reason for such a step. ${ }^{63}$

Secondly, China's substantial presence in the Arctic caused the need to declare its interests to partners in order to avoid the alarmism. The PRC has ceased to be a newcomer to the Arctic. Now, China has the material and technical capabilities, scientific and economic experience, a developed administrative structure, etc. In the absence of sounded intentions, the further participation of the PRC in mining projects of the Yamal LNG scale, an unprecedented breakthrough in the field of Arctic shipping and a significant influx of Chinese tourists could be a cause for concern. ${ }^{64}$ For this reason, the announcement of goals was a natural and reasonable step.

The third valuable reason is that China was found to be ready to offer its own vision for Arctic development, namely, the 'Arctic Silk Road' initiative. The ASR, which earlier appeared in documents, official statements, and experts' discussions, the first time, described that clearly in the White Paper - as a possible way of international cooperation for the development of the Arctic in the interests of humankind. ${ }^{65}$

This step is due to the fact, that by the time of publication, the ASR had appeared ex-post. Chinese companies have been actively involved in the development of Arctic navigation and significant infrastructure projects, and the northern regions have been striving to offer their own initiatives to get more investments

\footnotetext{
${ }^{62}$ Wang, "Jiyu SWOT fenxi fa yanjiu woguo beiji youqi hezuo zhanlue", 212.

${ }^{63}$ Dhruva, The rise and rise of Xi Jinping: At 19th Party Congress, he consolidates power to a degree unseen since Mao and Deng.

${ }^{64}$ Lim, "China's Arctic Policy \& the Polar Silk Road Vision", 428.

${ }^{65}$ The State Council of the People's Republic of China. Full Text: China's Arctic Policy.
} 
(such as the 'Heilongjiang Silk Road', the 'Dalian's Northeast Silk Road', the development of the Tumen River area, etc.) Therefore, as well as for regulating Arctic activities, China's leadership had a stake to consolidate all the activities into one grand state initiative. In addition, due to preliminary discussions and the lack of specific obligations on the participating in the ASR, some Arctic states have already expressed an interest to it. For example, Russia and Finland offered relevant initiatives, and the Nordic countries joined the Asian Infrastructure Investment Bank. ${ }^{66}$

Yet, assessing the prospect of the ASR as a path for international Arctic development, it is worth noting some challenges. Similar to the BRI, the ASR remains not a plan but literally an invitation to cooperation and dialogue. On the one hand, it gives flexibility for its implementation, on the other hand, it prevents participants from understanding the rules of the game. In this regard, the anxiety among the Arctic countries towards financial and technical difficulties of the ASR still prevail over the wish to get benefits of economic cooperation. Besides, Chinese identity of the project, enclosed in its name is also confusing. Most of the northern countries have no historical connection with the ancient Silk Road, and thus the ASR unlikely seem to the Arctic states a truly international initiative. For these reasons, it is worth saying that, despite China's achievements, the future of the ASR remains up in the air. However, the Arctic Silk Road is not the only chance for China's Arctic policy to succeed.

\section{Conclusions}

Firstly, the White Paper set the new level of China's policies in Circumpolar North. The articulated clear principles, priorities, and objectives became a guideline for the further development of the Arctic policy and the coordination of efforts of all policy actors. However, most importantly, the document confirmed the country's intention to build the ASR and identified the Arctic management as one of the key areas of the Arctic policy on an equal basis with the development of the region. From that moment, the construction of the ASR

\footnotetext{
${ }^{66}$ Kobzeva, “Arkticheskiy vektor v politike Kitaya pri novom rukovodstve”, 963, 972; Xinhua News Agency. Full text: Vision for Maritime Cooperation under the Belt and Road Initiative; China News. Zhongguo zhu e dashi: Dazao "bing shang sichou zhi lu” dui zhong e jun you zhongyao yiyi; Liu, “'Yidai yilu' zhanlue beijing xia de beiji hangxian kaifa liyong", 117.
} 
will accumulate economic efforts and become a tool for the implementation of China's national interests in the Arctic. The Arctic governance, in its turn, will unite the development of intangible components: the institutional and law-making participation, which includes further development of the 'discursive power' of China.

Secondly, the White Paper united two controversial components of China's policy: the adherence to the principles stated by the Arctic Council and to the existing legislation, and, at the same time, the intention to uphold the legitimate rights of non-Arctic actors and improve legislation in favor of greater openness. Thus, the pragmatic approach which allowed the PRC to develop different diplomacy in regard to Arctic actors involves now clear arguments for the interpretation of laws and a key tool - participation in the Arctic governance. In this regard, despite the commitment to the existing legal regime, in a situation conducive to legal changes, the PRC will be an activist towards the rights of non-Arctic countries. If China succeeds in this sphere, that will significantly influence the awareness of China's new role both in the Arctic and globally.

Thirdly, the analysis of the provisions of the White Paper allows for the defining of principles that constitute the essence of the future policy of the PRC in the Arctic. The first component is the Arctic image, according to which China is simultaneously a 'near-Arctic state', a 'responsible power', an 'important and legitimate stakeholder'. The second one is an assertion of China's rights to develop Arctic resources and navigation, to participate in the Arctic governance, and, as a result, the obligation of the PRC to protect the legal rights of other non-Arctic countries. The third one is the intention to contribute to the "shared future for mankind in the Arctic', through the implementation of the ASR as well. ${ }^{67}$ Such a combination will be at the heart of Chinese politics in the Arctic - both in the present and in the future.

\section{References}

2016 Pacific Arctic Group (PAG), Fall Meeting Minutes. Ocean University of China. Qingdao. (2016): 24. https://pag.arcticportal.org/documents/category/43-pag-october-2016- (accessed December 14, 2016)

Arctic Council. Arctic Council Observer Manual for Subsidiary Bodies. As adopted by the Arctic Council at the Eighth Arctic Council Ministerial Meeting. Kiruna, Sweden. Arctic Council Secretariat. Fram Centre. May 15. 2013: 15.

Baranikova, A.O., and Qiujie Chen. "Zhongguo beiji zhengce de xianzhuang yu qianjing" [China's Arctic Policy: Present and Prospects] Eluosi xue kan [Academic Journal of Russian Studies] vol. 2. (2012): 24-27.

\footnotetext{
${ }^{67}$ The State Council of the People's Republic of China. Full Text: China's Arctic Policy.
} 
Cai, Mejjang, COSCO. Arctic Circle 2015. https://vimeo.com/144905938 (accessed January 07, 2016)

China Daily. Yang, Jian. China has a key role in safeguarding the Arctic. 29.06.2012. http://europe.chinadaily.com.cn/epaper/2012-06/29/content_15535608.htm (accessed September 8, 2016)

China News. Zhongguo zhu e dashi: Dazao "bing shang sichou zhi lu" dui zhong e jun you zhongyao yiyi. [Chinese Ambassador to Russia: Building the 'Ice Silk Road' is of great significance to both China and Russia] 15.11.2017. http://www.chinanews.com/gj/2017/11-15/8376615.shtml (accessed November 21, 2017)

China-Nordic Arctic Research Center Newsletter. 3nd Issue. March 2015: 5. http://www.CNARC.info/images/newsletters/CNARC-Newsletter-3rd-issue.pdf (accessed September 29, 2016))

China-Nordic Arctic Research Center Newsletter. First Edition. December. 2013: 9. http://www.CNARC.info/images/newsletters/CNARC-Newsletter-1st-issue.pdf (accessed September 29, 2016)

CNPC. Ya ma'er, chuli beiji quan de LNG chaoji gongcheng. [Yamal, a super complex project for the production of LNG in the Arctic Circle] 01.04.2017. http://news.CNPC.com.cn/system/2017/04/01/001641559.shtml (accessed April 17, 2017)

Deng, Beixi. "Shipping Matters: The Role of Arctic Shipping in Shaping China's Engagement in Arctic Resource Development". Arctic Yearbook 2018. Special Section: China \& the Arctic. (2018): 59-70.

Dhruva, Jaishankar. The rise and rise of Xi Jinping: At 19th Party Congress, he consolidates power to a degree unseen since Mao and Deng. Brookings. 26.10.2017. https://www.brookings.edu/opinions/the-rise-and-rise-of-xi-jinpingat-19th-party-congress-he-consolidates-power-to-a-degree-unseen-since-mao-and-deng/ (accessed February 12, 2018)

Dou, Bo. "Dongbei ya sichou zhi lu yu zhongguo "yidai yilu" zhanlue de tazhan" [The Northeast Asian Silk Road and the Expansion of China's 'One Belt, One Road' Strategy] Renmin luntan [Peoples' Tribune] 29. (2016): 70-71.

Dwyer III, William G. "China's Strategic Interests in the Arctic." The U.S. Army War College. Joint Force Quarterly. NDU Press. (2016): 15.

Embassy of the PRC. Full text of Hu Jintao's report at 18th Party Congress. 27.11.2012. http://www.chinaembassy.org/eng/zt/18th_CPC_National_Congress_Eng/t992917.htm (accessed August 31, 2017)

Feng, Shoubo. "Zhongguo beiji zhengdang quanyi ying shou zunzhong" [China's Arctic legitimate rights and interests should be respected] Jiancha fengyun [Procuratorial View] no.12 (2018): 28-29.

Feng, Shoubo. "Zhongguo de beiji zhengce yu beiji shengtai huanjing gongtongti de goujian_—yi beiji huanjing guoji fazhi wei shijiao" [China's Arctic Policy and the Construction of the Arctic Eco-environment Community: From the Perspective of the International Rule of Law in the Arctic Environment.] Yuejiang xuekan [Yuejiang Academic Journal] no. 10 (2018): 96-108.

Feng, Yaru. "Beiji hangdao tonghang dui dongbei ya de zhanlue yiyi" [The strategic importance of navigating the Arctic routes for Northeast Asia] Shiji qiao 10. (2016): 90-92.

Global Times. China welcomes Arctic Council's granting of observer status. 16.05.2013. http://www.globaltimes.cn/content/781956.shtml\#.UZShr0pU1W8 (accessed April 14, 2017)

Hallding, K. China's Arctic Ambitions - actors, drivers and strategies? Stockholm Environment Institute. Sweden. 05.03.2013. http://www.arcticfutures.se/?tag=stockholm-arctic-seminar (accessed March 17, 2017)

Hallding, Karl. China's Arctic Ambitions - actors, drivers and strategies? Stockholm Environment Institute. Sweden. 05.03.2013. http://www.arcticfutures.se/?tag=stockholm-arctic-seminar (accessed February 21, 2015)

$\mathrm{He}$, Guangqiang, and Xiuju Song. "Chuangzaoxing jieru: Zhongguo canyu beiji diqu shiwu de tiaojian yu lujing tansuo" [Creative Involvement: The Conditions and Approach Explorations of China' s Involvement in Arctic Region Affairs] Taipingyang xuebao [Pacific Journal] vol. 21. no. 3. (2013): 51-58.

Hong, Nong. "China's Interests in the Arctic: Opportunities and Challenges". Institute for China-American Studies. (2018): 1-26.

Jakobson, Linda, and Syong-Hong Lee. "The North East Asian states' interests in the Arctic and possible cooperation with the Kingdom of Denmark." Report prepared for the Ministry of Foreign Affairs of Denmark. SIPRI, Stockholm (2013): 43.

Jiangnan Shipyard (Group) Co., Ltd. Woguo shou zhi jidi ke kao pobingchuan jiang yu niandi kaigong, jiangnan zaochuan yu jidi zhongxin qianding jianzao hetong [China's first polar scientific research icebreaker will start construction at the end of the year, Jiangnan Shipbuilding and the Polar Center signed a construction contract] 06.12.2016. http://jnshipyard.cssc.net.cn/compay_mod_file/news_detail.php?cart=3\&id=640 (accessed February 12, 2017)

Kobzeva, Mariia. "Arkticheskiy vektor v politike Kitaya pri novom rukovodstve" [The Arctic vector in the policy of China under the new ruling] Natsional'nyye interesy: prioritety i bezopasnost' 5. (2017): 962-974.

Kobzeva, Mariia. "Protivorechiya v otsenkakh arkticheskoy politiki KNR" [The conflict in assessments of China's Arctic behaviors] Konfliktologiya 2. (2017): 201-219. 
Komissina, Irina. "Arkticheskiy vektor vneshney politiki Kitaya" [China's Arctic foreign policy agenda] Problemy natsional'noy strategii 1. (2015): 54-73.

Konyshev, Valery, and Alexander Sergunin. "Osvoyeniye prirodnykh resursov Arktiki: puti sotrudnichestva Rossii s Kitayem v interesakh budushchego" [The development of the natural resources of the Arctic: ways of cooperation between Russia and China in the interests of the future] Natsional'nyye interesy: prioritety i bezopasnost' 39. (2012): $2-9$.

Konyshev, Valery, and Alexander Sergunin. "Strategii stran Vostochnoy Azii v Arktike" [East Asian Strategies in the Arctic] Problemy Dal'nego Vostoka 6. (2012): 34-38.

Konyshev, Valery, and Mariia Kobzeva. "Politika Kitaya v Arktike: traditsii i sovremennost"' [China's Policy in the Arctic: Tradition and Modernity] Sravnitelnaya politika 1. (2017): 77-92.

Konyshev, Valery, and Mariia Kobzeva. "Shpitsbergen v arkticheskoy politike Kitaya" [Svalbard in the China's Arctic Behaviors] Vestnik VGU. Seriya: Istoriya. Politologiya. Sotsiologiya 4. (2016): 48-54.

Kossa, Martin. "The rise of China in the Arctic? Domestic motives, actors and international context." ISA Asia-Pacific Conference 2016. (2016): 1-19.

Krivorotov, Andrey K. "Arkticheskaya aktivizatsiya Kitaya: vzglyad iz Skandinavii” [China's Arctic revitalization: a view from Scandinavia] Kitay $v$ mirovoy $i$ regional'noy politike. Istoriya $i$ sovremennost' [China in world and regional politics. History and modernity] vol. 18. no. 18. (2013): 158-192.

Lajeunesse, Adam, Finding 'Win-Win' - China's Arctic Policy and What it Means for Canada. The School of Public Policy Publications. (2018): 1-10.

Li, Jingyu, Zhan, Lunglung, and Ping Ma. "Zhongguo kaifa haishang dongbei hangdao de zhanlue tuijin gouxiang" [China's strategic vision for the development of the Northeast Passage] Dongbei caijing daxue xuebao 2. (2014): 4351.

Li, Zhen, and Maixiu Hu. "Beiji hangdao" kaitong yu zhongguo ji qi shou yingxiang quyu de maoyi zengzhang qianli fenxi". [The impact of using the Arctic route on trade in China and its accessible areas) Jidi yanjiu [Chinese Journal of Polar Research] vol. 27. (2015): 429-438.

Li, Zhenfu. "Da beiji shijiao xia de fan dongbei ya" [Pan-Northeast Asia from the perspective of the Big Arctic] Zhongguo chuan jian [China Ship Survey] no. 8. (2016): 26-28.

$\mathrm{Li}$, Zhenfu. "Ruhe zhunque lijie zhongguo de beiji zhengce' [How to accurately understand China's Arctic policy] Zhongguo chuan jian [China Ship Survey] no. 3 (2018): 37-39.

$\mathrm{Li}$, Zhenfu. "Zhongguo canyu beiji hangxian guoji jizhi de zhang'ai ji duice" [Obstacles to China' Participation in the International Arctic Route Mechanism and Countermeasures] Zhongguo hanghai 32. Part 1. (2009): 98-103.

Liao, Qian. "Beiji dalujia falu zhidu yanjiu" [Research on the legal system of the Arctic continental shelf] Liaoning xingzheng xueyuan xuebao 12. (2012): 63-65.

Lim, Kong Soon. "China's Arctic Policy \& the Polar Silk Road Vision.” Arctic Yearbook 2018 (2018): 420-436.

Liu, Huirong. "'Yidai yilu' zhanlue beijing xia de beiji hangxian kaifa liyong" [Analysis of the importance and significance of the Arctic sea routes in the context of the 'One Belt and One Road' strategy] Zhongguo gongcheng kexue 18. (2016): 111-118.

Liu, Nengye. "How Has China Shaped Arctic Fisheries Governance?" The Diplomat. (June 20, 2018) https://thediplomat.com/2018/06/how-has-china-shaped-arctic-fisheries-governance/ (accessed November 19, 2018)

Liu, Nengye. Why is China so quiet in negotiations about fisheries in the central Arctic Ocean? The conversation. 05.12.2016. https://theconversation.com/why-is-china-so-quiet-in-negotiations-about-fisheries-in-the-centralarctic-ocean-69654 (accessed March 11, 2017)

Lu, Fanghua. "Nuowei dui si wa'er ba de qundao guanxia quan di xingzhi bianxi - yi yun si pi ci bei er gen qundao tiaoyue zui wei shijiao" [An Analysis of the Nature of Norway's Jurisdiction over Svalbard - From the Perspective of the Svalbard Treaty] Zhongguo haiyang daxue xuebao. Shehui kexue ban. (2014): 7-12.

Mearsheimer, John J. Can China Rise Peacefully? The National Interest. 25.10.2014. https://nationalinterest.org/commentary/can-china-rise-peacefully-10204 (accessed May 05, 2017)

Ministry of Foreign Affairs of the People's Republic of China. Di er lun zhong ri han beiji shiwu gao jibie duihua lianhe shengming [Joint Statement on the Second High-Level Dialogue on the Arctic between China, Japan and South Korea ] 14.06.2017. http://www.fmprc.gov.cn/web/wjbxw_673019/t1470216.shtml (accessed August 27, 2017)

Ministry of Foreign Affairs of the People's Republic of China. Wang Yi buzhang zai di san jie beiji quan luntan dahui kaimu shi shang de shipin zhici [Minister Wang Yi's video address at the opening ceremony of the $3^{\text {rd }}$ Arctic Circle Forum]. 17.10.2015. http://www.fmprc.gov.cn/web/wjbzhd/t1306854.shtml (accessed November 12, 2015)

Ministry of Foreign Affairs of the People's Republic of China. Wang Yi: Zhongguo bingcheng zunzhong, hezuo yu gong ying san da zhengce linian canyu beiji shiwu [Wang Yi: China participates in the Arctic affairs with three major policy concepts of respect, cooperation and mutual benefit] 16.10.2015. http://www.fmprc.gov.cn/web/wjbzhd/t1306851.shtml (accessed January 27, 2016) 
Ministry of Foreign Affairs of the PRC. Zhang Ming. Vice-Foreign Minister, PRC. Keynote Speech by Vice Foreign Minister Zhang Ming at the China Country Session of the Third Arctic Circle Assembly. 17.10.2015. http://www.fmprc.gov.cn/mfa_eng/wjbxw/t1306858.shtml (accessed April 20, 2017)

Ministry of Land Reform. Zhongguo jidi kaocha gongzuo zixun weiyuanhui di 17 ci huiyi zai shanghai zhaokai. [The 17th meeting of the Chinese Advisory Committee for Polar Research was held in Shanghai] 04.07.2016. http://www.mlr.gov.cn/xwdt/hyxw/201607/t20160704_1410530.htm (accessed August 5, 2016)

National People's Congress (NPC) of the People's Republic of China. "Shisanwu" tixian zhongguo guojia zhanlue de bai da gongcheng xiangmu [The 13th Five-Year Plan reflects the top 100 projects of China's national strategy] 05.03.2016. http://www.npc.gov.cn/npc/sjb/2016-03/05/content_1969229.htm (accessed August 29, 2017)

National People's Congress. Zhangdejiang dui fenlan jinxing zhengshi youhao fangwen [Zhang Dejiang pays an official friendly visit to Finland] 25.09.2016. http://www.npc.gov.cn/npc/xinwen/2016-09/26/content_1998286.htm (accessed September 28, 2016)

$\mathrm{Ni}$, Haining, and Ming Li. "Zhongguo beiji zhengce de xianzhuang yu qianjing" [The status quo and prospects of China's Arctic policy] China's Ministry of National Defense. 12.02.2016. http://www.mod.gov.cn/opinion/201602/12/content_4640521.htm (accessed November 2, 2017)

Nilsen, Thomas. "Details of China's nuclear-powered icebreaker revealed." Barents Observer. 21.03.2019. https://thebarentsobserver.com/en/arctic/2019/03/details-chinas-nuclear-powered-icebreaker-revealed. (accessed March 21, 2019)

Østreng, Willy. et all. Shipping in Arctic Waters. A comparison of the Northeast, Northwest and Trans Polar Passages. Springer. Berlin. (2013): 414.

Pan, Min. "Self-Organization: The Governance of CAO Fisheries in the Global Commons" U.S.-Sino Relations in the Arctic: A Roadmap for Future Cooperation. Editor Conley H.A. CSIS. (2017): 20-22.

Pan, Zhenxian, and Lu, Zheng. "Beiji diqu de zhanlue jiazhi yu zhongguo guojia liyi yanjiu" [Strategic Value of the Arctic Region and study of China's National Interests] Jianghuai luntan 2. \{2013): P. 118-123.

People's Daily. Shou lun zhong ri han sanguo beiji shiwu gao jibie duihua zai shou'er juxing [The first round of the China-Japan-South Korea High-Level Dialogue on Arctic Affairs was held in Seoul] 28.04.2016. http://world.people.com.cn/n1/2016/0428/c1002-28312509.html (accessed October 21, 2017)

People's Daily. Zhong e gong jian zha lu bi nuo gang. [China and Russia jointly build the port of Zarubino] 22.09.2014. http://paper.people.com.cn/gjjrb/html/2014-09/22/content_1480021.htm (accessed October 20, 2017)

Port of Dalian. Dalian gang jiji mouhua "dongbei xinsilu". [Dalian Port actively plans the "Northeast branch of the New Silk Road"] 30.07.2015. http://www.portdalian.com/rdxw/2015/325/153258371755ha6498096937a6g052.html (accessed October 26, 2015)

Rainwater, Shiloh. "Race to the north: China's Arctic strategy and Its implications." Naval War College Review 66.2 (2013): 62-82.

Sina Corp. Zhongguo huo chao gangkou 30 nian shiyong quan han mei cheng xi liyong chaoxian [Korean media said that China has obtained the rights to use the port of North Korea for 30 years] 12.09.2012. http://finance.sina.com.cn/world/yzjj/20120912/071013113360.shtml (accessed October 14, 2015)

Sino-Nordic Relations: Opportunities and the Way Ahead. Report, Institute for Security and Development Policy. (2016): 49.

Sørensen, Camilla TN, and Ekaterina Klimenko. "Emerging Chinese-Russian cooperation in the Arctic: Possibilities and constraints." Stockholm International Peace Research Institute. no. 46. (2017): 43.

Sørensen, Nørup, C. T. "China as an Arctic Great Power. Potential Implications for Greenland and the Danish Realm." Royal Danish Defence College. (2018): 1-6.

Staalesen, Atle. "Murmansk counts on Chinese investors." Barents Observer 14.03.2017. https://thebarentsobserver.com/en/industry-and-energy/2017/03/murmansk-counts-chinese-investors (accessed March 15, 2017)

Stensdal, Iselin. “Asian Arctic Research 2005-2012: Harder, Better, Faster, Stronger.” Fridtjof Nansen Institute Report. no.3. (2012): 39.

Sun, Kai, and Peiqing Guo. "Beiji zhili jizhi bianqian ji zhongguo de canyu zhanlue yanjiu" [Research of the Change of Arctic Governance Mechanism and China's Participation Strategy] Shijie jingji yu zhengzhi luntan 2. (2012): 118128.

Sun, Kai. "Future Trends of Arctic Sustainable Development and Opportunities for U.S.-China Cooperation" U.S.-Sino Relations in the Arctic: A Roadmap for Future Cooperation. Editor Conley H.A. CSIS. (2017): 23-24.

The State Council Information Office of the People's Republic of China. Zhang, Zhizhou. "Guoji huayu quan jianshe zhong ji da jichu xing lilun wenti" [Several Fundamental Theoretical Issues in the Construction of International Discourse Power] 27.02.2017. http://www.scio.gov.cn/zhzc/10/Document/1543300/1543300.htm (accessed October 17, 2018) 
The State Council of the People's Republic of China. Full Text: China's Arctic Policy. 26.01.2018. http://english.gov.cn/archive/white_paper/2018/01/26/content_281476026660336.htm (accessed September 21, 2018)

Tonami, Aki. "Asian Foreign Policy in a Changing Arctic. The Diplomacy of Economy and Science at New Frontiers." Palgrave Macmillan. (2016): 140.

Tulupov, Dmitry. "Skandinavskiy vektor arkticheskoy politiki Kitaya" [The Scandinavian Vector of China's Arctic Policy] Mirovaya ekonomika i mezhdunarodnyye otnosheniya [World economy and international relations] no. 9. (2013): 61-68.

Wang, Yiwei, and Bailu Cui. "Yidai yilu" kuangjia xia de beiji guoji hezuo: Luoji yu moshi" [International Cooperation on the Arctic Under the Belt and Road Initiative: Logics and Models] Tongji daxue xиebao (shehui kexue ban) [Journal of Tongji University (Social Science Section)] no. 29 (2018): 48-58.

Wang, Yue, and Lei Wang. "Zhongguo ruhe yingdui beiji diqu xingshi xin bianhua" [How China should respond to new changes in the Arctic situation] Dangdai jingji 3. (2013): 34-36.

Wang, Yue. "Jiyu SWOT fenxi fa yanjiu woguo beiji youqi hezuo zhanlue" [Study on China's Arctic Oil and Gas Cooperation Strategy Based on SWOT Analysis] Zhongguo kuangye 25. (2016): 209-214.

Washington Post. Chinese naval ships came within 12 nautical miles of American soi. 04.09.2015. https://www.washingtonpost.com/world/national-security/chinese-naval-ships-came-within-12-nautical-miles-ofamerican-soil/2015/09/04/dee5e1b0-5305-11e5-933e-7d06c647a395_story.html?utm_term=.4e9951ee36d4 (accessed September 14, 2017)

$\mathrm{Wu}$, Chunping, Wu, Gang, and Xiaolin Wang. "IMO Jidi guize he weilai jidi chuanbo fazhan qushi fenxi" [Analysis of the development trends of the IMO Polar Code and the future of the polar ships] Zaochuan jishu 2. (2014): 6-9.

$\mathrm{Wu}$, Zhaochun. "Xijinping quanqiu jingji zhili de xin sixiang yu xin shijian" [Xi Jinping's New Thoughts and Practices in Global Economic Governance] Tanqiu 3. (2017): 11-17.

Xinhua News Agency. China's ice breaker sets sail for Arctic rim expedition. 20.07.2017. http://news.xinhuanet.com/english/2017-07/20/c_136458956.htm (accessed September 15, 2017)

Xinhua News Agency. Full text: Vision for Maritime Cooperation under the Belt and Road Initiative. 20.06.2017 http://news.xinhuanet.com/english/2017-06/20/c_136380414.htm (accessed July 28, 2017)

Xinhua News Agency. Shouquan fabu: Zhonghua renmin gongheguo guojia anquan fa [Official publication: National Security Law of the People's Republic of China] 01.07.2015. http://news.xinhuanet.com/politics/201507/01/c_1115787801.htm (accessed October 25, 2017)

Xinmin, M. A. "China's Arctic policy on the basis of international law: Identification, goals, principles and positions." Marine Policy. no. 100 (2019): 265-276.

$\mathrm{Xu}$, Guangmiao. "Interesy i politika Kitaya v Arktike: istoriya, pravovyye osnovy i realizatsiya" [China's interests and policies in the Arctic: history, legal framework and implementation] Mirovaya ekonomika $i$ mezhdunarodnyye otnosheniya 2. (2016): 52-62.

Yang, Huigen. "Chinese Arctic Activities in 2015 \& 2016" FARO meeting ASSW 2016. 12-15 March. Fairbanks, USA. 12.03.2016. http://faroarctic.org/fileadmin/Resources/DMU/GEM/faro/China_report_to_FARO_ASSW_2016_.pdf (accessed January 22, 2017)

Yang, Xiao. "Diyuan keji xue yu guojia anquan: Zhongguo beiji ke kao de zhanlue shenyi" [Geophysics and national security: the strategic meaning of the Chinese Arctic scientific expedition] Guoji anquan yanjiu 6. (2015): 106-131.

Yang, Zhenjiao, Liu, Xuexia, and Meijun Xin. "Woguo zengqiang zai beiji diqu shi zhi xing cunzai de shixian lujing yanjiu" [Study of a realistic scenario for the expansion of China's substantial presence in the Arctic] Taipingyang xuebao 10. (2015): 75-81.

Zha, Daojiong. Arctic Geopolitics: a view from China Arctic Frontiers 2015. [http://www.arcticfrontiers.com/downloads/presentations-3/monday-19-january/857-11-zha-daojiong-arcticgeopolitics-a-view-from-china/file (accessed February 1, 2016)

Zhang, Cheng, and Deming Huang. "Zhongguo beiji quanyi de weihu lujing yu celue xuanze" [The Maintenance Route and Strategy Choice of China's Arctic rights and Interests] Huadong ligong daxue xuebao (shehui kexue ban) [Journal of East China University of Science and Technology (Social Science Edition)] vol. 30. no. 6. (2015): 7384.

Zhao, Long. "Lun eluosi beifang hangdao zhili lujing ji qianjing pinggu" [On the governance path of Russia to the Northern Sea Route and assessment of its future development] Shijie dili yanjiu [World geography research] vol. 25. no. 2. (2016): 21-29. 